
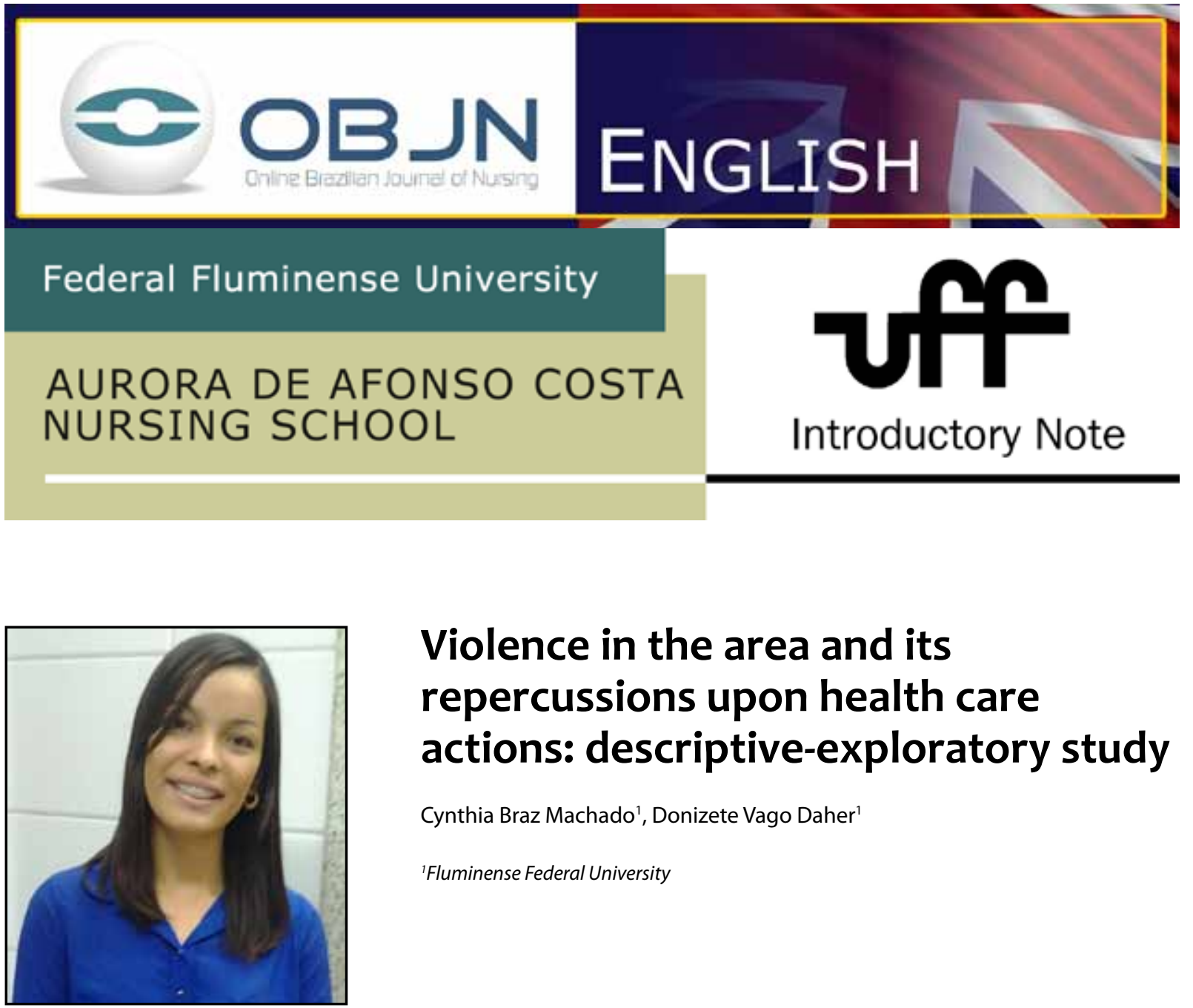

\title{
Violence in the area and its repercussions upon health care actions: descriptive-exploratory study
}

Cynthia Braz Machado', Donizete Vago Daher ${ }^{1}$

'Fluminense Federal University

\section{RESUMO}

Study related to the Academic Master Degree Program in Health Care Science at Fluminense Federal University that will mention the repercussions of violence upon health care actions in the Family Doctor Program (FDP). Aims: to know the health care professionals perception in relation to the violence in the program area; to identify the repercussions of violence upon health care actions taken by the FDP professionals and to describe the strategies apprehended by the FDP professionals to face the violence in the area.

Method: descriptive-exploratory study to be accomplished in FDP units in Niteroi city, state of Rio de Janeiro. Health care professionals who work at FDP units for at least 6 months will participate in the research. The gathering of data will be through a semi structured interview, which will begin in November 2013 and end in January 2014. The analysis of gathered data will be done through content analysis

Descriptors: Violence; Primary Health Care; Family Health. 


\section{PROBLEM SITUATION AND ITS SIGNIFICANCE}

Violence is a subject that is being pinpointed nowadays and discussed in many public health care congresses and debates in Brazil. The health area has been emphasizing the theme due the fact that violence impacts the morbidity and mortality indexes within the population, besides causing great expenditures for the Unified Health Care System (UHCS) with actions of recovering and rehabilitation of individuals who suffered violence. Violence has been expressed by epidemiological and criminal indexes through lethal and non-lethal events greater than countries in war ${ }^{(1)}$. Nowadays violence represents a challenge to health professionals due to the fact they base their procedures in cause-effect relationship, consequence of biomedical model of their background. However, so they can act in face of violence, it is necessary to think and work in health in an integral way, considering its biological, social and psychological sense ${ }^{(2)}$. In this way, the repercussions of violence in health care action in the Family Doctor Program (FDP) area have been selected as the issue of this study. It has become a challenge to the professional to take actions of health care of individuals, families and communities in an integral way, respecting and saving their knowledge and actions, their subjectivities, singularities and necessities in face of daily occurrences of several kinds of violence.

\section{MAIN QUESTION}

What are the repercussions of violence in the area upon health care actions taken by professionals from FDP units in Niteroi, Rio de Janeiro state?

\section{AIMS}

General

To know the FDP health care professionals'perception in relation to violence in the program area.

\section{Specifics}

To identify the repercussions of violence upon health care actions taken by health care professionals who work in the FDP area.

To describe the strategies apprehended by the FDP professionals to face violence in the area.

\section{METHOD}

Descriptive exploratory study with a quality approach, as it is based on the description of experiences, which allows the identification of others subjectivities ${ }^{(3)}$. The study will be accomplished in four FDP units in Niteroi city, Rio de Janeiro state. A sample of dimensioned convenience to reach at least $50 \%$ of professionals who work at each researched unit, attaining, this way, ten health care professionals in each unit, totalizing 40 individuals. The criteria of inclusion will be: Brazilian adults, FDP health care professionals with at least six months of work in each unit, and as a criterion of exclusion: professionals with different off-work reasons. There will be a field research and the data gathering will be through a semi structured interview that will follow a script elaborated by the researchers and after its application in a preview test.

\section{REFERENCES}

1. Souza ER, Lima MLC. Panorama da violência urbana no Brasil e suas capitais. Ciênc saúde 
coletiva [Internet]. 2012 [cited 2013 May 28]; 11(Suppl):1211-22. Available from: http://www. scielo.br/pdf/csc/v11s0/a11v11s0.pdf

2. Oliveira CC, Almeida MAS, Morita I. Violência e saúde: concepções de profissionais de uma Unidade Básica de Saúde. Rev bras educ méd [Internet]. 2011 [cited 2013 Apr 14]; 35 (3): 412-20. Available from: http://www.scielo.br/pdf/rbem/ v35n3/a16v35n3.pdf

3. Trigueiro TH, Labronici LM. Chemical dependency as a risk factor for domestic violence against women. Online braz j nurs [Internet]. 2011 Oct [Cited 2013 Sept 24]; 10 (2): [about 5 p.]. Available from: http://www.objnursing.uff. br/index.php/nursing/article/view/3266. http:// dx.doi.org/10.5935/1676-4285.20113266

\section{Project Data}

Dissertation project presented to Academic Master Degree Program in Health Care Science at Fluminense Federal University.

Approved by Ethics and Research Committee (ERC) of University Hospital Antonio Pedro (UHAP) on July 10, 2012 under number 53792/2012, CAEE 04612912.6.0000.5243.

Financial support: None

Orientation: Prof Dr Donizete Vago Daher

Received: 03/09/2013

Revised: 13/09/2013

Approved: 15/09/2013 